\title{
REVISITING IBSEN'S HEDDA GABLER THROUGH DURKHEIM'S SOCIOLOGICAL SUICIDE: A BODY TO END THE DOOM OF ORGANIC SOLIDARITY
}

Muhammad Hussein Oroskhan, Department of English Literature, Faculty of Foreign Languages, Yazd University, Yazd, Iran, h.oroskhan@gmail.com

Asghar Moulavinafchi, English language and literature Department, Hakim Sabzevari University, Sabzavar, Iran, a.moulavi.n@gmail.com

Original scientific paper

DOI: 10.31902/fll.33.2020.4

UDC: 821.113.5.09 Ibzen $\mathrm{H}$.

\begin{abstract}
The debate over Henrik Ibsen's Hedda Gabler sometimes constitutes the belief that all of the interpretations over the play should be learned from a feministic perspective. Closer readings of Ibsen's play noting Georg Brands' categorization of Ibsen's plays and Peter Wessel Zapffe's exceptional perspective spurred a new reading of Ibsen's Hedda Gabler in our mind. Hence, a discussion of it in relation with sociological issues is proved to be highly effective in dissecting different layers of meaning from Hedda Gabler's tragic ending. As such, Emile Durkheim's sociological model of suicide is recommended as a reliable platform to become the mainstay of the Ibsen's Hedda Gabler's discussion. Under the purview of sociological issues, Ibsen's Hedda plays the role of a literary description of an individual entangled in the modern world unavoidably committing suicide to free herself from the limitations of the modern world.
\end{abstract}

Keywords: Sociology, Suicide, Egoistic Suicide, Hedda Gabler.

With Ibsen's $A$ Doll's House, for almost the first time, a male writer seemed to be trying to support the women's right. That being the case, even some critics attested to the importance of this work in contributing to the movement of feminism in the following years. Nonetheless, Ibsen himself has never asserted the same view but has attempted to even distinguish his work from the feministic movement; I thank you for the toast, but must disclaim the honor of having consciously worked for the women's rights movement. ... True enough, it is desirable to solve the woman problem, along with all the others; but that has not been the whole purpose. My task has been the description of humanity (Ibsen 337). 
Ignoring Ibsen's view, radical feminists continued labeling Ibsen's A Doll's House as a great feministic work. However, twelve years later when Ibsen published Hedda Gabler, most of these critics were left befuddled by Ibsen's new perspective. Suddenly, negative reviews took precedence over the positive reviews of A Doll's House. For instance, Jens Arup, a well-known Norwegian critic accorded no value to Ibsen's Hedda Gabler and denigrated its main character as a criminal figure committing the most horrific act of crime; "Hedda repeatedly goes much too far. How can we identify ourselves with her when she moves through a career of crime so wanton and so sordid, above all so willfully unreasonable, exaggerated, lacking in judgement?" (14). Adding to such negative views, in some of the theatrical productions of the play, Hedda is portrayed as "a wittily sardonic bitch who kills herself in a moment of pique" (Durbach 144). Surely, one of the most caustic comments passed on Hedda was made by G. B. Shaw in his Quintessence of Ibsenism (1891). His extrapolation on Hedda is narrowed down to "a decadent who lacked both the courage and the intelligence to become genuinely free" $(2018,35)$. The main reason behind such debates over Ibsen's Hedda Gabler is that none of these critics accorded enough significance to Ibsen's comments justifying his main theoretical framework behind his works. He has repetitively presented the same view after releasing each of his works. For $A$ Doll's House, he mentioned that the focal point should be centered on the "description of humanity"; again he repeated more or less the same view after writing Hedda Gabler to his translator but adding more explanations to it:

It was not my purpose to deal with what people call problems in this play. What I principally wanted to do was to depict human beings, human emotions and human destinies upon a groundwork of certain of the social conditions and principles of the present day. (Ibsen 435)

Seemingly, depicting human being in a social context is Ibsen's main purpose behind his works especially his Hedda Gabler. However, through the passage of time, critical confusion has never thoroughly abated, not because Ibsen's creation of Hedda is an all confounding figure puzzling critics constantly but because critics are highly tended to initiate their discussion based upon the concept of feminism. Even recent critics have tried to make a new reading out of Hedda Gabler, but still each time prioritizing the concept of feminism within the whole discussion. Jenny Björklund reads Hedda's behavior as an indicator of "female masculinity". She believes that the debates over the character of Hedda is limited to labeling him as "a defective 
woman, as vicious and manipulative in nature, as a failed new Woman, or as a woman who is afraid of sex" (1). To this end, she adds that a new perspective should be developed to contribute to a better categorization of Hedda as her character is not consistent with the women's role of her time. She notes that the failure of justifying a stable role for Hedda within the concept of feminism alerts us to the fact that "she embraces masculinity, and her masculinity is conveyed primarily in her desire for a man's life" (8). For her, Hedda's suicide at the end of the play stems from Hedda's female masculinity that "might pose a threat to hegemonic masculinity which is absorbed into the dominant structures and thus disarmed" (15). Interestingly, her conclusion put aside the concept of feminism by turning to a general perspective of how society is affecting the relationship among men and women. Such attempts to categorize Hedda within a specific feministic view are even expanded to its theoretical production. Ann M. Shanahan as a director of Ibsen's Hedda Gabler spurred a new production of Hedda Gabler in terms of incorporating new feministic views in its production. She narrates Hedda Gabler within a new spatial ordering. She ventures for a new perspective which can open up "theatrical expressions that can include female creativity without necessitating destruction or departure" (62). For her, Ibsen has drawn enough attention to "women's limited options in the space" (64), therefore, a new spatial ordering in the production of Hedda Gabler would result in an accurate portrayal of Hedda's feministic issues. And at last she emphasizes that Hedda's death is the result of "the restriction of women in the fourth-wall frame" (64). Moreover, in another recent study, again Toril Moi (2013) has taken his bearings on Hedda Gabler from a feministic view and drawing to this conclusion that "Ibsen's play is both feminist and universal" (438). Besides the earlier feministic studies conducted on Hedda Gabler which were mainly negating the significance of the play, the recent studies are not also truly developing a genuine understanding of Hedda Gabler, be it from a female masculinity viewpoint or from a universal feminism viewpoint; each one neglects a fundamental point, the question of humanity which was never neglected in Norway. That Ibsen mainly craved for answering of this question can become more palpable for the readers when a famous Norwegian critic named Peter Wessel Zapffe (1889-1990) seems to be in the path of seeking an answer for this question while reading Ibsen's plays for the first time; ... "he (Zapffe) had a revelatory encounter with the plays of Ibsen and reentered university to attack 'the ever burning question of what it means to be human'" (Tangenes). Zapffe was born at a time when 
Ibsen was spending his last years of writing for the theater. Unlike Ibsen, his talent was not instantly realized around Europe and remained undiscovered due to the lack of the translation to other European languages. To explain to what extent Zapffe's fame would have cast more widely if he had been translated to other languages, we can suffice to Eriksen's comment on Zapffe's The Last Messiah which is a short version of his treatise On the Tragic published during World War II:

This masterpiece was written at the same time as Sartre was working out the doctrine later to be world-famous as Existentialism. Sartre wrote in a world language, while Zapffe's Dano-Norwegian was never translated. Had it been published in German, English or French, the book might have been a classic today. (Eriksen)

The claim embedded in Eriksen's comment on Zapffe's contribution should never be found unsubstantiated as Zapffe's The Last Messiah truly revolves around the exigencies of what it means to be a human. As such, as soon as The Last Messiah was being extended to other languages though not at an early time, it was couched in profuse praise because Zapffe employed a language closer to common parlance to explicitly corroborate his view of humanity. His article fills a serious lacuna in our understanding of the concept of knowing in the position of human being in the society. For him, knowing is a fundamental device for comforting life, moreover, he emphasizes that it can be transformed to the main source of problem when it goes beyond the horizons of necessity. In explication of this concept, he tallies it with the capsids of a lion when they overgrow and pierce the mouth of lion and kill the lion or in another metaphor resembling it to the antlers of a deer with the same function. Then he interprets the human mind when evolution occurs as an overdone action "akin to how a contemporary of the hunter, a deer misnamed the 'Irish elk', became moribund by its increasingly oversized antlers" (Tangenes). The central tenet that pervades and dominates the whole of Zapffe's The Last Messiah is the moment when the human being aspires to know more and more until seriously hurting him/herself. Consequently, the individual is alienated and secluded from the external world or, in other words, the external world is not responding to these individuals as he/she cannot find the answer to his/her curiosity. Surely, this perspective provides a pessimistic view of the world not synonymous with the people's common view of the world.

This is precisely the platform on which Ibsen had previously tried to speak from and shared his view of the world. To foster a better 
discussion of this important figure, Gerog Brands in his pivotal work on Ibsen entitled Henrik Ibsen: Critical Studies, brings up Ibsen's works under the purview of three stages; the first one beginning with Castilian (1850) to Peer Gynt (1867), the second one from The league of Youth (1869) to Ghosts (1881), and the last stage including Hedda Gabler begins from 1882 to 1896 . Brands' categorization is with the purpose of marking one certain line within all Ibsen's works asseverating his main mindset behind his plays. Sketching a general point, he introduces Ibsen as a person "who looks upon the life of the present day with the eye of pessimist... whose pessimism is of a moral character, akin to contempt and indignation" (2). Upon Brands' eyes, Ibsen's pessimistic view of the society describes an individual who finds $\mathrm{him} /$ her self not matched with the external world. Unavoidably, the individual ends with a tragic ending:

These spiritual forces must have air, and require room. Life has no room to spare, and to procure it they seek to revolutionize this society that lies rotting in stagnation. But the revolution does not end in reform; the "comedy" of love is really its tragedy, and the drama of will ends in martyrdom. (3)

Brands believes that Ibsen recruits the social inadequacy into his service of harsh criticism for explicating the reason behind the failure of the individual ending in martyrdom. As such, one can never dispense with Ibsen's plays unless taking a more social perspective toward his plays. Drawing further attention to this issue, Hedda Gabler's puzzling features should be studied from a more general perspective, in other words, explaining Hedda's mysterious ending through a sociological view and not just studying her character in the feminism framework. Moreover, a discussion of Ibsen's plays through a sociological perspective proves more effective when we see that Ibsen's last stage of writing is coincided with the ending of nineteenth century, the years accompanied by vast socio-political changes in every aspect of human life. The considerable scope of these changes provided a new world of complexity. Consequently, these drastic changes in society were reflected in the reformation of social relationships among people. As a result, new social theorists began to interpret the emerging world. This being the case, the first sociological theorist who tried to shed new lights on the impact of the modern world and on the lives of the individual was Emile Durkheim (1858-1917). He clearly expressed his views regarding the concept of sociology as follows;

Sociology is to study norms and not individual attitudes, social imperatives and not the reaction of the average man to the average 
man's picture of the social order. For the sociologist, it is only in relation to the normative system of beliefs and to the sanctioned channels of action that individual conduct becomes meaningful. (Durkheim 15)

Durkheim's clear manifestation of the concept of sociology shows his special focus on the effect of rules and regulation generated by the society to the extent which these rules are affecting the lives of individuals in the society. Therefore, for analyzing the life of modern man, one needs to probe the structure of society first and then examine its impact on the individual. Durkheim's initial consideration of the changes occurring in the modern society was really optimistic. He labeled the shift from the traditional society to the modern society as a shift in the manners of individuals trying to connect with each other. He further asserted that changes in the modern society have gathered the people around in terms of organic solidarity rather than the previous association of mechanical solidarity. According to him, "while mechanical solidarity was founded upon likeness, organic solidarity arose because of complementarity between actors engaged in different pursuits" (16). Nonetheless, in his later works, Durkheim notices a deviation in the established norms of organic solidarity in the modern society. His further studies revealed that if the individual who is supposed to be integrated and regulated by the society is alienated and lost in the modern world due to his insufficient relation with the society, he/she will contemplate death in its most horrific form which is the form of suicide. For Durkheim, "suicide is used by as a means of demonstrating the key impact of social factors on our personal lives and even our most intimate motives" (Durkheim \& Spaulding 1). For Durkheim, the act of suicide is a logical ending not a dramatic one as previously assumed by Brands. Hence, the act of suicide is less an end in itself than a manifestation of a moment produced from so many different forces. Incidentally, approaching this topic through Durkheim's perspective bear fruit in better understanding the varying degrees of this tragic ending of one's life.

To discover the causes of suicide, one should search the social network in which the individual has been dealing with it through his/her life. In this regard, Durkheim assigns the act of suicide not to be the category of individual's behavior but to be the effect of social relationships in which the individual is situated. Durkheim's perspective reveals that the main cause of suicide in the modern world lies in "the loss of mechanical solidarity and the failure to develop a genuine organic solidarity" (Durkheim \& Thompson 264). On the 
account of this, the individual is left desolate devoid of any social support and forced to seek his/her goals on his/her own accord. For Durkheim, an inevitable consequence of this situation is that the individual's needs take precedence over individuals' goals and consequently, he/she is lost in the modern world, unless he/she is led through by means of an external force;

Human nature in itself cannot set variable limits to our needs. Consequently, in so far as it is left to the individual alone, these needs are unlimited. Without reference to any external regulating influence, our capacity for sensation is a bottomless abyss that nothing can satisfy (Durkheim \& Thompson 78).

Hence, the central problem of modern society is the lack of any barrier to abilities of human. Durkheim searches for the reasons behind the non-existence of any social force on human behaviors in the modern society and is drawn to the conclusion that the degree of social integration and regulation define the relation of the individual with society. When the human being is not facing any barrier and is not directed in a society toward a defined goal, he/she is led to nowhere. Accordingly, seeking a goal that is literally unreachable by the individual leads one to a state of unreachable unhappiness. Durkheim believes that when the individual is entangled in a state of unhappiness, he/she is consequentially led to commit suicide. Durkheim clarifies the process that leads the individual to suicide in the modern society in this way;

Old forms of organization which had integrated individuals and regulated means-end relationships had declined and disintegrated (e.g. family, Church, occupational guilds, etc.). No adequate functional substitutes had been developed, and so there were pathological states of social disequilibrium, of which suicide rates were a symptom. (Thompson 378).

Durkheim's definition of the concept of suicide varies with regard to the consequence of social integration and moral regulation into four types of egoistic, altruistic, anomic and fatalist suicides. In this respect, Thorlindsson and Bjarnason (1998) have studied Durkheim's notion of suicide and carefully analyzed these four types of suicides in simple terms. They explain them in the following terms;

Too little integration leads to a state of loneliness and egoistic suicide; Too much integration leads to altruistic suicide when the perceived interest of the social group is set above personal interests; Under regulation causes anomic suicides of individuals lost in a chaotic 
universe; Over regulation results in fatalistic suicides. (Thorlindsson \& Bjarnason 96)

It is manifested in the above definition of different types of suicide that the modern society is to a great extent faced with two types of suicides namely the egoistic suicide and the anomic suicide. Both of these two types are the results of individuals left abandoned in a boundless society without any constraint limiting and controlling the individual's behaviors and actions. Though, Durkheim has recruited each type for explicating different situation, he himself believes that these two types are merely following the same path: "it was very difficult to separate the currents of egoism and anomie as they flowed from a single source-the loss of mechanical solidarity and the failure to develop a genuine organic solidarity" (Thompson 90). Nonetheless, on the purpose of distinguishing between these two types of suicide, Durkheim has mentioned the underlying cause of each one by proposing that;

In the case of egoistic suicide, lack of integration gave rise to meaninglessness and so to states of apathy, melancholy, and depression. In anomie suicide, insufficient regulation had left individual passions and wants unchecked, leading to irritation, disgust, anger, disappointment, or recrimination. (96)

This being the case, it seems that lbsen as one of the fathers of modern drama has prophesized Durkheim's works specifically his Suicide written in 1897. As such a discussion of Ibsen's Hedda Gabler through Durkheim's sociological view of suicide can shed new light on Ibsen's particular figure who is Hedda Gabler. The reason that makes the usage of Durkheim's theory justifiable is that his primary point is not solely regarding the transition of society from a traditional form to an industrial form whereas he is fully concerned with the effect of this transition on "the cohesion and solidarity of societies" (21), because some previous studies have explored Ibsen's Hedda Gabler with regard to social conditions of Norway. For instance, Erling E. Kildahl in his article "The Social Condition and Principles of Hedda Gabler" has studied Hedda Gabler with regard to social changes of its time. He mentions that when Hedda Gabler was produced by Ibsen, Norway experienced great economic changes;

Economic upheaval accompanied the political shifts. Crown lands became available to everyone by public sale; laws governing the borrowing of money were liberalized; lumbering and manufacturing 
industries were broadened and intensified; commerce with other nations and within Norway quickened the pulse of life. (207)

Moreover, in the consideration of Hedda Gabler, this should be noted that Ibsen has tried to cast his net broadly, creating a universal type not just a specific one related to Norway; "Hedda herself is an international type; a product of civilization by no means peculiar to Norway"(Ibsen, Herford and Archer xii). As a result, the occurrence of these changes is noteworthy and should be taken into consideration as a sign demonstrating the whole situation around the world on the verge of modernization. In a like manner, Durkheim affirming the existence of these changes is focusing on the effect of these changes among the relationships of the individuals and more importantly the consequences of the individuals being free to choose their own path in a modern society. To explain what he means, we can suffice to his commentary on the occurrences of these drastic changes in modern society. He believes that "as evolution advances, the bonds that attach the individual to his family, to his native heath, to the traditions that the past has bequeathed him, to the collective practices of the group all these become loosened" (332). The same situation can be seen in the beginning of Hedda Gabler when she talks about herself experiencing a new situation away from her family and close friends; Hedda: Fortunately. Of course one has always to accustom one's self to new surroundings, Miss Tesman-little by little. [Looking towards the left.] Oh, there the servant has gone and opened the veranda door, and let in a whole flood of sunshine. (Ibsen 16)

Due to changes in the society, Hedda is now experiencing a new situation. Previously she could easily find herself within the scope of her families and friends; now she is undergoing some rough time adapting herself to a new situation. In a society based on mechanical solidarity, the individual can easily go through the course of time with regard to the instructions of the society as there is a shared system of values and beliefs, nonetheless, in the modern time when the individuals are associated together with regard to the basis of organic solidarity, each individual should carve a niche for him/her self. On this account, the individual is not strictly instructed and controlled by the society whereas the individual can now develop his/her own individualistic identity and establish him/her self as a separate entity communicating with the other individuals based on complementary needs. Here is Hedda's struggle to carve a new status for herself since previously she never needed to do so as the daughter of General 
Gabler. Relatively, Hedda's unaccustomed situation is well described when Berta is talking to Aunt Julie regarding Hedda's behaviors;

Berta: Most like she'll be terrible grand in her ways. Aunt Julia: Well, you can't wonder at that-- General Gabler's daughter! Think of the sort of life she was accustomed to in her father's time. Don't you remember how we used to see her riding down the road along with the General? In that long black habit-and with feathers in her hat?. (3)

When the individual and the society are thoroughly integrated, society will play the role of a protector by keeping individuals under its control and providing them with efficient and adequate services. In a situation like this, Durkheim believes that "the society instead of throwing the individual on his own resources leads him to share in the collective energy and supports his own when exhausted" (Durkheim, Lukes \& Halls 169). The aforementioned society works through the interaction of ideas; hence, the individual feels to be a part of the meaningful world rather than feeling insignificant. Clearly, Hedda is devoid of experiencing a supportive society which can help her find her ways around and is left desolate mulling over her situation without making any progress. Hedda's dissatisfaction in adapting herself to the new situation is persistently shown whenever she talks with George Tesman. As an example, when George asks her to call his aunt 'dear', she rejects George's proposal and in response to George's assumption to consider her to be a member of the family, she says; "H'm-I can't in the least see why" (Ibsen 24). Clearly, Hedda cannot understand the situation in which she is lost. Though she put all her efforts to understand her surrounding, she is still bewildered and amazed at what is happening around her. She is only attached to her piano which is a remembrance of her old time when she was in her father's house. Even she cannot see her piano matched with this new situation; "I'm only looking at my old piano. It doesn't go at all well with all the other things" (24). Clearly, Hedda cannot make a connection with anything other than the old piano which is a remembrance of her old associations.

As it is indicated, Hedda is experiencing what Durkheim has called the abnormal circumstances of individuals who are passing from mechanical solidarity to organic solidarity. As such, the individual is lost and alienated from the external world without ever finding any compelling reason for living in this world. For Durkheim, "society is the existence of a certain number of beliefs and practices common to all" (Durkheim \& Thompson 73). In this regard, Hedda is an exception as she is not following the common beliefs shared by all the other people. 
As such, Hedda shows her boredom living in this manner while talking to Judge Brack; "Oh, my dear Judge-you cannot imagine how horribly I shall bore myself here" (Ibsen 78). Durkheim believes that "passions, desires, appetites, ends, and goals could all become needs, and if such wants were not restrained they would bring unhappiness" (Thompson 88). Hedda's lack of power in attaching herself to anybody in this world shows her frustration in settling her needs and aims. In line with Hedda's frustration in the newly emerging world, Ibsen planted a symbolic element hypothetically referring to this new world. When Eilert Lovborg is explicating the content of his new book to George Tesman, he mentions that; "I dictated it. It falls into two sections. The first deals with the civilizing forces of the future. And here is the second-[running through the pages towards the end]-forecasting the probable line of development. (Ibsen 87)

Here, Loveborg's comment is highly apropos since it implicitly reveals two predominant features. First and most, it refers to new forces shaping the civilization and the world and secondly, it determines the possible outcomes of these transformations getting to grips with the world. Seemingly, Ibsen's referring to Loveborge's manuscript proves his urgent need of writing on these fundamental changes occurring in the world that are influencing the people's relationships around the world. Moreover, it was noteworthy to refer to the book written by Loveborg because the book gains seminal importance when it is finally burnt out completely by Hedda. While burning it Hedda says; "Now I am burning your child, Thea!-Burning it, curly-locks! [Throwing one or two more quires into the stove.] Your child and Eilert Lovborg's. [Throws the rest in.] I am burning-I am burning your child" (153). Hedda's words express her bitter disagreement with the emergence of these new changes in the world, therefore, her effort of burning the manuscript which is metaphorically called a child is indeed attested to her detestation of the born of the new situation expressed in this manuscript. Hedda's abhorrent view of this changing world is better expressed when she tells Judge Brack how she is unfitted in this new world; "I had positively danced myself tired, my dear Judge. My day was done -- [With a slight shudder.]" (67).

To understand the extent to which Hedda is lost in this modern world and how her desires and passions are pushing her toward nothingness, it is best suited to refer to the time when Hedda hears about Eilert Lovborg committing suicide. She says; "Oh, what a sense of freedom it gives one, this act of Eilert Lovborg's" (Ibsen 174). To everybody's amazement, Hedda portrays Loveborg's act of suicide as the only possible way of releasing oneself from this meaningless world. 
She further explains Loveborg's suicide in this way; "It gives me a sense of freedom to know that a deed of deliberate courage is still possible in this world, a deed of spontaneous beauty" (174). On the contrary, Thea's case is not synonymous with Hedda in any of the perspectives on life, be it on Loveborg's suicide or on life in general. Hedda's description of Loveborg's suicide is confronted with Thea's objection; "No, you must never think that was how it happened! It must have been in delirium that he did it" (171). Thea's attempt to label Loveborg's suicide as an act of delirium reveals not only Thea's successful adaptation with the new organization of the society based on organic solidarity but also justifies Loveborg's suicide as a reaction out of his feeling of being guilty due to losing the manuscript for which he had devoted a considerable amount of effort and not just because of experiencing a meaningless situation in this world. In the same respect, Thea's view of Loveborg's suicide can show her well-situated position within the organic solidarity of the new society. That is why she answers to Tesman's request of forgetting about Loveborg's death and helping him with finishing his books like this; "Yes, yes, Mr. Tesman, I will do the best I can" (174). In this view, one should not be dependent on others whereas should pursue his/her goal in the society. Clearly, Thea's concern with her goal which is the publication of a book on the "march of civilization" (30) helps her to come to terms with this difficult situation and get along with her life. Durkheim asserts that "no living being can be happy or even exist unless his needs are sufficiently proportioned to his means" (207). On the other side, Hedda, whose needs and means are not in the same line, finds no meaning in this world and is entangled in an endless conflict between her inner self and the society. As such, she praises Loveborg's act of suicide as an act of utmost beauty saving one from this meaningless world.

As mentioned previously in this paper, Emile Durkheim has categorized different types of suicide based on different social causes. The root causes of his categorization were social integration and regulation. Worthy of note is Durkheim's tendency to carry the concept of suicide beyond the level of individual and relate it to the level of an interaction between the individual and the society. He believes that society should recruit the individual into a certain categorization confined by proposed restriction; otherwise, the individual would face a considerable challenge finding his own path within this world;

Society alone can perform a moderating role, either directly and as a whole, or through the agency of one of its organs; for it is the only moral power superior to the individual, whose authority he accepts. 
[...] When society is disturbed, either by a painful crisis or by favorable, but abrupt, changes, it is temporarily incapable of exercising this action; and it is then that we get those sudden rises in the curve of suicides that were noted earlier. (Thompson 78).

To Durkheim's opinion, in a moment like this, an individual decides to commit suicide. He noted further that the two types of suicide are the result of society being insufficient for the individual, yet the realm of each type influencing the individual is different; anomie is caused when society is unable to regulate or restrain the individual, while the egoistic suicide is caused by the individual's absence in any social activity. To stem the causes of Hedda's suicides, one can search the roots of egoistic suicide growing and controlling Hedda. Before Ibsen gets to the final act of Hedda's suicide, he describes Hedda doing some actions which clearly refers to her lack of integration with the society. When there is a mournful atmosphere caused by the death of Aunt Rina and of Eilert Loveborg ruling over the house; "Suddenly she (Hedda) is heard playing a wild dance on the piano" (Ibsen 185). By offering a marked contrast, she is indeed referring to her detachment from her surrounding world. Moreover, as her final act before committing suicide, Hedda is described closing the curtain. Hedda's act of closing the curtain is believed to show "her complete withdrawal from a reality she cannot accept" (Blythe \& Sweet 79). And indeed, it is truly an avoidance of reality since Hedda can never feel to be part of this newly emerging world which is growing rapidly more than making it possible for Hedda to catch with its speed of changing. As such, Ibsen's description of Hedda before her act of suicide can aptly match with Durkheim's reasoning behind the concept of egoistic suicide which is the lack of integration on the side of the individual in dealing with the society. Finally, she commits suicide which is described in Tesman's word as follows; "Shot herself! Shot herself in the temple! Fancy that!" (Ibsen 187). Surely, for Hedda, an act of suicide was the only option to fancy in an incomprehensible and indifferent world that is not responding to her. In addition, Brack's comment is really apropos in elucidating Hedda's suicide. He reacts to her suicide by saying that "Good God!-people don't do such things" (187). Brack's amazement reveals a critical point with respect to one's situation in a modern world by extrapolating that the individuals in a modern society should interact with each other based on their needs and aims and not expecting the society to push them forward automatically. Hence, Brack who supposedly thinks that Hedda has committed suicide due to avoiding being embroiled in a scandal is totally consternated because previously he had offered her how to escape being involved in 
Loveborg's suicide. In a similar manner, Durkheim asserts that "when, we have no other object than ourselves we cannot avoid the thought that our efforts will finally end in nothingness" (Durkheim, Lukes \& Halls 169). Therefore, Hedda is experiencing the same situation. She just finds herself in this world without being connected to anything. She finds that all her efforts are coming to nothing, and then she decides to ruin her body as the only thing which is left in this world supposedly connecting her to everything in it.

\section{Conclusion}

The new female character created by Ibsen in 1891 when he published his Hedda Gabler, was never as popular as his Nora in $A$ Doll's House. Responses to Hedda Gabler became more and more caustic since it confounded critics' expectations and eased them to put it in the same line as $A$ Doll's House. The number of feministic interpretations carried upon Hedda Gabler could have come into justifiable conclusion only if two things never had happened in the play; firstly, if Hedda had never praised Loveborg's suicide as an utmost act of beauty and secondly, if she herself had never committed suicide. If the play had ended without the last scene of Hedda committing suicide, one could easily relate her depression to her maltreatment of others and consider Hedda's suicide as a defensible ending for the play, consequently, all her devilish labeling could be acceptable but her appreciation of Loveborg's suicide and her own suicide at the end of the play opens a new window for the readers to interpret the play differently and beyond solely the level of feminism. Not ending the play without suicide and dropping enough hints that Hedda's suicide is not an act of feeling guilty like Loveborg whereas an act of one's releasing from this meaningless world in which one's efforts would lead to nowhere, needs us to approach the play from a totally different perspective relying on a more general framework. Indeed, Ibsen has tried to take issue with an abnormal but prevalent act in the societies on the verge of modernization. As such, it is enough to say that Ibsen has encapsulated in his plays specifically in his Hedda Gabler what Emile Durkheim as the father of sociologist explained in his theoretical book, Suicide. Durkheim imagines the individual while being lost in an unregulated and indifferent society, ergo suicide is the unavoidable fate of him/her. This being the case, Ibsen's Hedda Gabler has truly satisfied a literary description of an individual being entangled in a transformed and indifferent world. His play has drawn constant 
attention; however, not a specific critical study ${ }^{16}$ from Durkheim's perspective has well been conducted on Hedda Gabler. A sociological perspective was necessarily needed since Ibsen's creation of his main female character is for the purpose of portraying the individual in a society which is suddenly disarranged; therefore, individual's previous situation is abruptly disturbed. As such, Hedda's last moments of shutting herself away from other peoples and committing suicide can best be matched with Durkheim's theory of individual committing suicide when he/she is unable to make an appropriate connection with the external world. Hence, in Hedda's opinion, the best option was to eliminate the only connection she had with this world which was her body. Ironically, her suicide is the only time in which her means and needs are following the same line.

\section{References}

Arup, Jens. “On Hedda Gabler?" Orbis Litterarum, vol. 12, no. 1, 1957, pp. 3-37., doi:10.1111/j.1600-0730.1957.tb01823.x.

Björklund. "Playing with Pistols: Female Masculinity in Henrik Ibsen's Hedda Gabler." Scandinavian Studies, vol. 88, no. 1, 2016, p. 1., doi:10.5406/scanstud.88.1.1.

Blythe, Hal, and Charlie Sweet. "Ibsen's Hedda Gabler." The Explicator, vol. 59, no. 2, 2001, pp. 78-79., doi:10.1080/00144940109597089.

Brandes, Georg. Henrik Ibsen, a Critical Study: with a 42 Page Essay on Björnstjerne Björnson. Ayer Co. Publishers, 2000.

Durbach, Errol. Ibsen and the Theatre: the Dramatist in Production; New York Univ. Pr., 1980.

Durkheim Émile, and Kenneth Thompson. Readings from Emile Durkheim. Routledge, 2005.

Durkheim Émile, and Mark Traugott. Emile Durkheim on Institutional Analysis. University of Chicago Press, 1994.

Durkheim Émile, et al. The Division of Labour in Society. Palgrave Macmillan, 2013.

Durkheim Émile. Sociology and Philosophy. Routledge, 2010.

\footnotetext{
${ }^{16}$ Joachim Schiedermairin in his article entitled "Agents of Secularisation-lbsen and the Narrative of Secular Modernity" tries to read the concept of secularization as part of cultural narrative that accompanies other modernist upheavals. In this regard, he explicates how different sociological ideas like secularization coming from theorists like Émile Durkheim, Ferdinand Tönnies, Georg Simmel, and Max Weber are reshaped and put into a different narrative by literary authors in their literary productions.
} 
Durkheim, Emile, and Mustafa Emirbayer. Emile Durkheim: Sociologist of Modernity. Blackwell, 2006.

Durkheim, Emile. Suicide: a Study in Sociology. Snowballpublishing, 2013.

Eriksen, Thomas Hylland. Engaging with the World, 2016, www.hyllanderiksen.net/.

Ibsen, Henrik, and William Archer. The Works of Henrik Ibsen. Willey Book Co., 1924.

Ibsen, Henrik, et al. Letters of Henrik Ibsen. University Press of the Pacific, 2002.

Kildahl, Erling E. "The 'Social Conditions and Principles' of 'Hedda Gabler.'" Educational Theatre Journal, vol. 13, no. 3, 1961, p. 207., doi:10.2307/3204828.

Marber, Patrick, and Henrik Ibsen. Hedda Gabler. Faber \& Faber, 2017. Meyer, Michael Leverson. Ibsen: a Biography. Doubleday, 1971.

Moi, Toril. "Hedda's Silences: Beauty and Despair InHedda Gabler." Modern Drama, vol. 56, no. 4, 2013, pp. 434-456., doi:10.3138/md.s89.

Schiedermair, Joachim. "Agents of Secularisation-lbsen and the Narrative of Secular Modernity." Humanities, vol. 8, no. 2, 2019, p. 111., doi:10.3390/h8020111.

Shanahan, Ann M. "Un-'Blocking' Hedda and Medea through Feminist 'Play' with Traditional Staging Forms." Theatre Topics, vol. 21, no. 1, 2011, pp. 61-74., doi:10.1353/tt.2011.0000.

Tangenes, Gisle. "The View from Mount Zapffe." Philosophy Now: a Magazine of Ideas, 2016, philosophynow.org/issues/45/The_View_from_Mount_Zapffe.

Templeton, Joan. Shaw's Ibsen: a Re-Appraisal. Palgrave Macmillan, 2018.

Thompson, Ken. Emile Durkheim. Routledge, 2007.

Thorlindsson, Thorolfur, and Thoroddur Bjarnason. "Modeling Durkheim on the Micro Level: A Study of Youth Suicidality." American Sociological Review, vol. 63, no. 1, 1998, p. 94., doi:10.2307/2657479. 


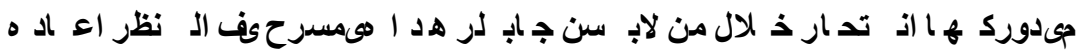

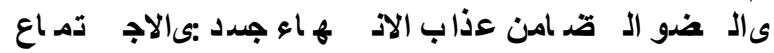

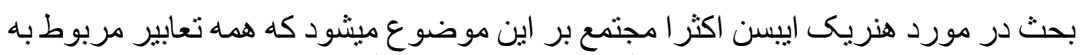

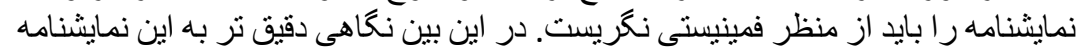

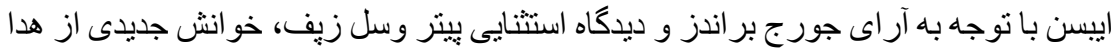

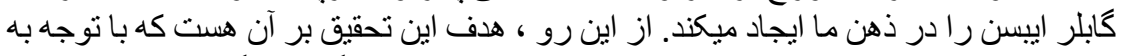

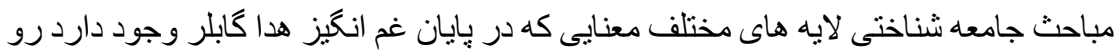

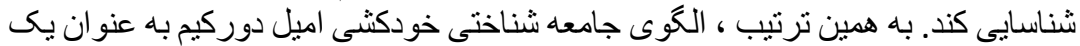

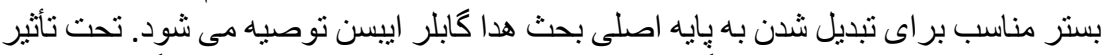

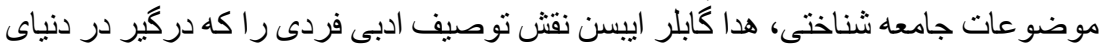
مدرن هست و به طور اجتناب.

كلمات المفتاحيه: الغرب الامريكى، راعى البقر، الذات الاثثويه و الساخره الليبر اليه 